\title{
Flask or Bottle Culture
}

National Cancer Institute

\section{Source}

National Cancer Institute. Flask or Bottle Culture. NCI Thesaurus. Code C112954.

A type of culture in which cells are grown in flasks or bottles. 